\title{
Impact of Financial Inclusion on Consumption Expenditure in Kenya
}

\author{
Isaac Mwangi ${ }^{1} \&$ Rosemary Atieno ${ }^{2}$ \\ ${ }^{1}$ Research and Policy Analysis Department, Central Bank of Kenya \\ ${ }^{2}$ Institute of Development Studies, University of Nairobi, Kenya \\ Correspondence: Isaac Mwangi, Central Bank of Kenya, Box: 60000-00200 Nairobi, Kenya. Tel: \\ 254-721-395-781. E-mail: wamwabz@gmail.com
}

Received: April 5, 2017

Accepted: March 29, 2018

Online Published: April 10, 2018

doi:10.5539/ijef.v10n5p114

URL: https://doi.org/10.5539/ijef.v10n5p114

\begin{abstract}
The main agenda of this study is to explore the impact of both single (transactionary, credit, savings and investment, insurance and pension) and composite (portfolio usage) measures of financial inclusion on household welfare in Kenya. To address this, the study makes use of repeated household Financial Access datasets over 2009-2016 to apply dynamic panel regression methods. The results show that the observed differences in welfare varies by financial product with the credit channel taking the lions share. A zero to one change from non-usage (control) to usage (treatment) of credit, transactionary and insurance products among Kenyan households was found to be statistically significant in raising household welfare ceteris paribus. Similarly, the coefficient of the constructed index of financial inclusion was found to be both positive and statistically significant in explaining household welfare. Given the significant role financial inclusion plays in enhancing welfare, the study recommends a reduction in transactionary costs through an increase in the range of formal financial products to raise competition in financial markets. Policies targeting welfare improvement through finance should also be aligned to specific financial inclusion transmission channels to be more effective as opposed to policy formulation based on economic aggregates.
\end{abstract}

Keywords: welfare, endogeneity, financial inclusion, consumption

\section{Background}

Poverty and inequality remains a major challenge to many Kenyans despite the rapid economic expansion in the last two decades. Empirical evidence revealed that a surge in financial inclusion (FI) promotes inclusive growth perceived to be critical towards reducing poverty and income inequality (Park \& Maercado, 2014). This poverty reduction goal is achieved through contingency plans targeting the young and old-age populations such as retirement pensions, financial contracts enforcement and financial regulatory oversight. FI cushions economic agents against unexpected short term shocks enabling them to make consumption and investment decisions over a long period. This facilitates the crafting of policy initiatives geared towards raising access to a broad range of affordable financial services for poverty reduction. This study interrogates the impact of FI on welfare by first constructing both sigle and composite measures of FI using household survey data. Measurement of FI followed Sarma (2008) definition of access, availability and usage of formal financial services.

The economic pillar of Vision 2030, Kenya's economic blueprint and financial sector Medium Term Plan (MTP), of the period 2012-2017 recognize FI as key in promoting economic growth and poverty alleviation (GoK, 2003) in Kenya. This positive link between FI and growth is also supported by both theoretical and empirical evidence (World Bank, 2002; DFID, 2004; Rajan \& Zingales, 1998). Literature on financial inclusion and how it's linked to economic welfare however remains scanty. This is compounded by lack of a universally acceptable definition and measure of FI which limits impact studies. Research has shown that policy surrounding FI and its various outcomes is highly dependent on the adopted FI measures and definitions. Earlier theories of development made little mention of finance instead concentrating on labour and capital to reduce income inequality and accelerate economic growth.

Some of the poverty eradication programs rolled out in Kenya include; Welfare Monitoring Surveys (1992, 1994 and 1997); Millennium Development Goals (UN, 2000); and the Economic Recovery Strategy for Wealth and Employment Creation (GoK, 2008). Inspite of the domination of FI in global policy discussions on growth and development, 
The paper contributes to the existing body of knowledge through 1) developing both single and composite measures of FI in line with Sarma (2008) formulae 2) examining the contribution of each financial measure on the overall household welfare over time using Deaton (1985) pseudo panel technique on repeated household survey data from Kenya 3) drawing policy recommendations to improve FI and its welfare impact. Estimation results from the five autoregressive distribution lagged models (transactionary, credit, savings, insurance, composite index of FI) on consumption per adult equivalent revealed that differences in the observed household welfare depend on the FI product. Use of transactionary and credit products exhibited a stronger positive impact on household welfare vindicating the ongoing reforms in the financial sector.

The rest of the paper is organized as follows: section two captures the overview of literature. Section three the empirical framework and data. Section four the key findings and lastly section five offers the conclusion and policy implications.

\section{Literature Review}

\subsection{Theories on the Link between Financial Inclusion and Welfare}

Theories linking FI and welfare are transmitted through either direct or indirect channels. FI in the direct channel improves household welfare by reducing income inequality and poverty through broadened access to transactionary, credit, savings and insurance products. This avails resources for meeting day to day transactions for consumption, investment and overall economic growth (King \& Levine, 1993; Rajan \& Zingales, 1998). This literature stream extends early theories linking growth, development and finance based on capital, labour and institutions where finance is captured as a regressor in a growth function. Copestake (2007) suggests that FI provides a platform for reducing poverty especially in low income countries. The direct channel is however limited by information asymmetry that often characterize credit markets (Stiglitz \& Weiss, 1981; Levine, 2008; Aghion \& Bolton, 1997).

FI under the indirect channel operates through the finance growth stimulation nexus of financial development. This theory is traced back to Schumpeter (1934); Modigliani Miller theory; Fama (1970) and Mckinnon (1973) though it's also supported by the financial structuralist theory which associates well developed financial systems to economic growth (Aghion \& Bolton, 1997). Schumpeter (1934) emphasized the role of banks in spurring economic development. Greenwood and Jovanocovic (1990); King and Levine (1993) associate financial development to increased productivity from the savings allocative efficiency. Endogenous growth theories (Romer, 1986) echoed similar sentiments by stating that accumulation of savings and capital mobilization by financial intermediaries improve technology and economic growth. The trickledown theory also in support of the indirect channel associates poverty reduction with economic growth as wealth is redistributed from the rich to the poor (Aghion \& Bolton, 1997).

The finance growth nexus is anchored on four major theoretical underpinnings namely; supply leading or finance led growth hypothesis (Schumpeter, 1911; McKinnon, 1973; Merton, 1988; Chuah \& Thai, 2004), demand following hypothesis or growth led finance (Robinson, 1952; Lucas, 1988; Demetriades \& Hussein, 1996); bi-directional causality hypothesis (Greenwood \& Jovanovic, 1990) and the independent hypothesis by Lucas (1988) and Stern (1989). Lucas (1988) and Stern (1989) however consider finance as an overstressed determinant of economic growth, even though recent literature has helped build a consensus that the finance-growth nexus holds.

Greenwood and Jovanovic (1990) nonlinear inverted U hypothesis portray a lower equilibrium in the early stages of development characterized by low risk less productive investments. Higher equilibrium emerges where markets are fairly developed and sophisticated by recent technology hence the high income inequality at the initial stages since only the rich are able to take advantage of the demand for financial services. The inequality falls once financial development spreads across the economy, benefiting the poor segments. Economic growth enhances FI as financial intermediation identifies persons with great potential for technological innovation.

Modern theories of development mainly focus on the evolution of growth, income inequality, persistence and benefits associated with an efficient financial system (Note 1). Financial market imperfections in capital accumulation theories shape decisions on human and physical capital accumulation through credit channels and the extent to which poor talented individuals can raise venture capital in theories touching on entrepreneurship. An efficient payment system facilitates better integration into modern market economies opening income earning opportunities for the poor. In particular, access to savings and credit enable the poor to overcome poverty through investment in human capital development and microenterprises as well as asset accumulation. Efficient savings, credit and insurance also facilitate consumption smoothing in the wake of transitory changes in both income and expenditure (Beck, 2016). 
Institutional quality is associated with welfare improvement through the indirect channel which feeds into household welfare through the economic growth channel The literature suggest that the quality of institutions shapes the incentives for investment in both physical and human capital, technological progress and innovations. The institutions also determine property rights and transaction costs which have serious implications on market size, specialization and technological progress (Dhrifi, 2013).

IMF (2015) presents four classifications of growth and development channels namely; endogenous growth model by Arrow (1962); Romer (1986) and Lucas (1962) where savings promote growth through the investment channel; capital allocation channel which tackles the information asymmetry problem through financial markets, institutions and instruments model where financial inflows are channeled to the domestic economy through the external sector and lastly the theoretical model which ties together financial constraints, economic growth, wealth inequality and poverty.

\subsection{Correlation between Financial Inclusion and Household Welfare}

Any study focusing on the welfare impacts of FI should include the control variables. Some of these variables include; income, occupation, price, education, occupation, age, household size, geographical location, macro variables such as interest rates, capital gains, savings, unanticipated shocks, consumer attitudes, liquidity constraints, expectations among others (Deaton, 2001; Zeldes, 2005; Eswaran \& Kotwai, 2006; Ravallion, 1995; Burney et al., 1991; Knight, Shi, \& Quheng, 2010; Jain \& Tendulkar, 1973). The following literature stream summarizes the link between FI and welfare. The trickle down effects of finance and economic growth on welfare outcomes such as consumption is huge (Todaro, 1997).

Randomized control trials (RCTS) by Gine and Townsend (2004) on intermediated and non-intermediated wage earners established a positive and significant difference in welfare. Previously constrained firms gained more efficiency in the scale of operations. A huge increase in household income of between 17-201 percent was established from the expansion in the financial sector. This is echoed by Jeong and Townsend (2007) model of occupational choice and financial deepening where positive gains to credit market expansion was established.

Buera et al. (2012) established credit expansion by upto one and a half times the annual wage boosts consumption by approximately 10 percent. Additionally, welfare gains from FI among the poor are greater, rising by approximately 8 percent of their permanent consumption in a general equilibrium framework. In a similar fashion, Kaboski and Townsend (2012) established a very strong relationship between financial intermediation and consumption. The impact however varied with households' participation in investment activities and whether one was a borrower or not. However, despite the personal income and business income rising with the increased intermediation, actual business startups stalled. Karlan and Zinman (2009) study on South Africa revealed that even though access to credit raised borrower wellbeing as well as income and food consumption, they were subjected to high stress levels. Bauchet et al. (2011), Attanasio et al. (2011), Pitt and Khandker (1998) also found a positive effect on household welfare.

A recent RCT in rural Western Kenya on female market vendors by Dupas and Robison (2013) established a significant link between savings and household expenditure. Again, private expenditure for the users of a savings product increased by 13 percent. Research indicates that results from studies focusing on the link between savings and household welfare are more positive and consistent as opposed to those focusing on the impact of credit usage. Notable though is that the impact also varies with the sampled population given that a similar RCT on rickshaw drivers reported conflicting results.

Not all studies however link financial intermediation with positive welfare effects (Bernerjee et al., 2015; Crepon et al., 2014; Angelucci, Karlan, \& Zinman, 2013). Bernerjee et al. (2015) for example in their randomized control trial on the role of micro credit failed to establish any positive link on average monthly consumption expenditure per capita 15 to 18 months later. Instead, households' expenditure on durables increased significantly leading to an increase in profitability. Crepon et al. (2014) posit that even though access to microcredit led to a significant increase in asset investment and profit, the gains were offset by a reduction in casual labour income hence neutralizing the overall consumption effect. Although credit to Mexican households revealed a general increase in their wellbeing, no significant effect was established between FI and household consumption, (Angelucci et al., 2013).

Tanzania's National Panel Survey (TzNPS), 2011 which mainly collects data on living standards presents a direct link between a range of financial services such as use of SACCO, formal bank, and mobile money on household consumption which is used in this chapter as a measure of welfare. The two wealthiest quintiles were found to take a lion's share in the access to financial services. Access also appeared skewed towards urban households. The report further claims that usage of savings, insurance and mobile financial services can help households 
escape poverty and mitigate against risks hence lower their vulnerability to poverty.

The reviewed literature therefore revealed a lack of consensus on the real impact of FI on welfare justifying more empirical investigation. It was found that the best way to understand the implications of FI on welfare is to look at the whole issue from a counter factual to establish what effect a lack of FI would have. The review also established that the impact varies with the individual financial products. Usage of savings product was found to have a positive significant and more consistent impact as compared to credit facilities. Studies carried out in Kenya in rural Western province targeting female market vendors and rickshaw drivers using RCT reported conflicting impacts. The twin tests yielded mixed evidence leaving the researcher with a number of questions as to the real effect of FI. This study aimed at filling this policy gap by offering solutions on the proportion of welfare difference attributable to a particular financial product. The study therefore investigates the role of transactionary, credit, savings and investment, insurance and pension as well as the generated composite index in enhancing welfare from a household perspective.

\section{Method and Data}

\subsection{Theoretical Framework}

Welfare estimation informs on policies relevant to boosting consumption and improved living standards. A household in the standard consumer theory maximizes utility from the available consumption basket subject to budget constraints. An observable measure of utility (consumption expenditure) is adopted as an indicator for individual welfare. Ravallion (1992); Murkherjee and Benson (2003) view consumption expenditure as a smoother, less erroneous and a more accurate measure of the standard of living as compared to income. By duality, expressing consumer decisions in terms of expenditure (cost) functions provides a monetary measure of the amount required to derive a given level of utility by a rational consumer. Other theories invoked when estimating a consumption function include; Keynes (1936) absolute income hypothesis (AIH), Duessenbery (1949) relative income hypothesis (RIH), Friedman (1957) permanent income hypothesis (PIH) and Ando, Modigliani and Blumberg (1963) life cycle hypothesis (LCH).

Sarma (2008) framework for the construction of an index of financial inclusion is expressed as follows;

$$
F I=1-\frac{\sqrt{\sum_{k=1}^{j}\left(\left(M_{k}-x_{k}\right) /\left(M_{k}-m\right)\right)^{2}}}{\sqrt{j}}
$$

where; $M_{k}$ represents the upper bound in number of financial products held, $\mathrm{m}$ the lower bound in number of financial products held, $\mathrm{k}$ the number of dimensions under investigation per product. The ratio $\left(M_{k}-x_{k}\right) /\left(M_{k}-\right.$ $m$ ) yields the shortfall from the maximum possible value. The index is generated from the usage of transactionary, credit, savings and insurance products derived from the 2009, 2013 and 2016 household FinAccess survey data. A portfolio usage of the products has been aggregated using Sarma (2008) formulae to construct the index of FI (IFI).

\subsection{Theoretical Model}

In line with the theory of consumer behavior (Keynes, 1936), a household maximizes utility from the consumption of a combination of physical goods, $\mathrm{Z}_{\mathrm{i}}$ and a range of financial services, $\mathrm{FI}_{\mathrm{i}}$ (treatment variable) subject to their disposable income, $Y^{\mathrm{d}}$. Since FI enhances pro poor growth, increase in consumption spending raises individual welfare through a reduction in poverty. Household welfare is expressed as a function of a vector of regressors, $\mathrm{X}_{\mathrm{i}}$ and financial inclusion (FI) which comprise both single and a portfolio of financial assets held by a household. The difference in the expected utility from the various financial products determines household choice (McFadden's random utility (RUM)).

The logarithmic transformation of consumption is expressed as follows:

$$
\ln C_{i, t}=X_{j, i, t}^{\prime} \beta+u_{j, i, t}
$$

Where; $\mathrm{C}$ - Consumption in KSh per adult equivalent; $\mathrm{i}$ - Household identification; $\mathrm{j}$ - Group cohort; $\mathrm{t}$ - time dimension; $\mathrm{X}$ - Vector of regressors and $\mathrm{u}$ - Stochastic error term. The error term is assumed not to be homoscedastic but varies with cohort based on individual characteristics. Log consumption is considered to be a smoother measure of welfare as compared to income which is more seasonal (Murkerjee \& Benson, 2003).

The linear projection of household consumption in the three waves of FinAccess is expressed as; 


$$
\begin{aligned}
& C_{i 1}=\beta_{1}^{\prime} x_{i 1}+\varepsilon_{i 1} . \\
& C_{i 2}=\beta_{2}^{\prime} x_{i 2}+\varepsilon_{i 2} \\
& C_{i 3}=\beta_{3}^{\prime} x_{i 3}+\varepsilon_{i 3}
\end{aligned}
$$

where; $x_{i j}$ be a vector of household characteristics observed in survey $j$ where $j=$ Survey 1,2 or 3 by household $i$, representing a particular cohort, $\mathrm{c}_{\mathrm{ij}}$ represents household consumption per adult equivalent in survey $\mathrm{j}$ where $\mathrm{j}=$ Survey 1,2 or 3 . The error term $\varepsilon_{i 1}, \varepsilon_{i 2}$ and $\varepsilon_{i 3}$ are assumed to follow a bivariate normal distribution characterized by a $\rho$ correlation coefficient and $\sigma_{i 1}, \sigma_{i 2}$ and $\sigma_{i 3}$ standard deviations.

The main assumption is that the sampled population in the three FinAccess survey datasets is identical. The beta parameters are estimated using GMM in a differenced consumption function where the lagged dependent values are used as instruments. The error component structure is assumed to have zero mean and constant variance and is expressed as;

$$
\varepsilon_{i 1}=f_{i}+v_{i 1}
$$

where $\mathrm{v}$ captures the idiosyncratic error term with zero mean while f captures the fixed effect. The GMM is applied to derive the parameters after which lagged values of the endogenous variable from an auxiliary regression are used as instruments in a dynamic model (Mckenzie, 2004). Estimating the dynamic model of welfare using grouped cohorts follows Verbeek and Vella (2005).

The specific model for the estimation of household welfare using consumption expenditure is expressed as;

$$
\begin{aligned}
& \overline{\ln \text { consumption }}_{c t}=\alpha+\beta_{1} \ln \overline{\text { income }}_{c t}+\beta_{2} \overline{\text { age }}_{c t}+\beta_{3} \overline{\text { agesq }}_{c t}+\beta_{4} \overline{\text { hhsize }}_{c t}+\beta_{5} \overline{\text { hhsqrd }}_{c t}+\beta_{6} \overline{\text { femhhead }}_{c t} \\
& +\beta_{7} \overline{\text { education }}_{c t}+\beta_{8} \overline{\text { married }}_{c t} \beta_{9} \overline{\text { residown }}_{c t}+\beta_{10} \overline{\text { socialcapital }}_{c t}+\beta_{11} \overline{F I}_{c t}+\bar{f}_{c t}+\bar{\lambda}_{c t}+\bar{\gamma}_{c t} \bar{\varepsilon}_{c t}
\end{aligned}
$$

The FI variable captured both the single product (transactionary, credit, savings and insurance) and the composite measures of FI (IFI) included in each autoregressive dynamic panel. Dynamic estimation of panel data followed the Arellano and Bover, 1995 estimator (system GMM). This method applies where the data has a small $\mathrm{T}$ and many $\mathrm{N}$ panels. Where $\mathrm{T}$ is large, the dynamic panel bias is insignificant. The inclusion of survey year dummies helps overcome the autocorrelation problem through the robust estimates. Under the two step robust procedure, the standard covariance matrix is robust to panel specific autocorrelation and heteroskedasticity.

The Sargan hypothesis test was used to assess whether Instruments in the GMM are jointly exogenous. The dependent variable (per adult equivalent log consumption expenditure) is specified as lagged differences. The lagged dependent variable in first differences is instrumented using the second lag of per adult equivalent consumption expenditure. The instruments set include survey year dummies and other individual characteristics.

The Arellano and Bond framework is expressed in the following equation where current value of the dependent variable is expressed as a function of the previous value.

$$
C_{i t}=x_{i t}^{\prime} \beta_{1}+C_{i(t-1)} \beta_{2}+\alpha_{i}+\varepsilon_{i t}
$$

Use of a conventional linear panel data estimation yields biased and inconsistent estimates due to the endogeneity bias where time invariant unobservable components are related to the independent variables. This problem is overcome through instrumenting using second lags of the dependent variable, a process that yields a set of moment conditions expressed as;

$$
\begin{aligned}
& E\left(\Delta y_{i(t-2)} \Delta \varepsilon_{i t}\right)=0 . \\
& E\left(\Delta y_{i(t-3)} \Delta \varepsilon_{i t}\right)=0 \\
& \ldots \ldots \ldots . . . \\
& E\left(\Delta y_{i(t-j)} \Delta \varepsilon_{i t}\right)=0
\end{aligned}
$$

The length of dimension T determines the number of GMM instrumental variables. The main problem associated with welfare estimation is endogeneity due to omission of variables, measurement errors and simultaneity bias (Wooldridge, 2012). Failure to control for this may lead to the rejection of a true null (Type I error) or failure to reject a false null (Type II error). FI and per adult equivalent consumption expenditure considered to be potentially endogenous were subjected to endogeneity tests. 
Table 1. Description of variables and apriori expectations

\begin{tabular}{|c|c|c|c|}
\hline Variable & Description & Expected sign & Authors \\
\hline Welfare & $\begin{array}{l}\text { Proxied by a money metric measure, that is, } \\
\text { consumption expenditure per adult equivalent }\end{array}$ & $\begin{array}{l}\text { Dependent } \\
\text { Variable }\end{array}$ & \\
\hline Log Income & $\begin{array}{l}\text { A continuous variable capturing per capita } \\
\text { income of household head }\end{array}$ & + & $\begin{array}{l}\text { FSD, 2014; Cull, Robert, Tilman Ehrbeck, and } \\
\text { Nina Holle, 2014; Beck et al, 2007; } \\
\text { Demirguc-Kunt and Klapper, } 2012\end{array}$ \\
\hline Age & $\begin{array}{l}\text { Continuous variable which forms the basis of } \\
\text { forming cohorts }\end{array}$ & + & Honohan and King, 2012; Allen et al., 2012 \\
\hline Age squared & A continuous variable with square age values & - & Honohan and King, 2012; Allen et al., 2012 \\
\hline $\begin{array}{l}\text { Female } \\
\text { household head }\end{array}$ & $\begin{array}{l}\text { A binary variable } 0 \text { and } 1 \text { representing female } \\
\text { household head }\end{array}$ & - & Demirguc-Kunt, 2013 \\
\hline Household size & $\begin{array}{l}\text { A continuous variable capturing the number of } \\
\text { family members }\end{array}$ & + & Honohan and King, 2012; Allen et al., 2012 \\
\hline $\begin{array}{l}\text { Household size } \\
\text { squared }\end{array}$ & $\begin{array}{l}\text { A continuous variable with squared household } \\
\text { size variable }\end{array}$ & - & Honohan and King, 2012; Allen et al., 2012 \\
\hline Education & $\begin{array}{l}\text { Number of schooling years; primary }-8 \text {; } \\
\text { secondary }-12 \text {; tertiary }-14\end{array}$ & + & Honohan and King, 2012; Allen et al., 2012 \\
\hline Urban & $\begin{array}{l}\text { A binary variable } 0 \text { and } 1 \text { for rural and urban } \\
\text { respectively }\end{array}$ & + & $\begin{array}{l}\text { McCullouch and Calandrino, 2003; Bidani and } \\
\text { Richter, 2001; Dang and Raghbendra, } 2009\end{array}$ \\
\hline Married & $\begin{array}{l}\text { A binary variable } 0 \text { and } 1 \text { for non-married and } \\
\text { married respectively }\end{array}$ & + & Zaman, 2004 \\
\hline Social capital & $\begin{array}{l}\text { A binary variable } 0 \text { and } 1 \text { for group } \\
\text { membership in a chama }\end{array}$ & + & $\begin{array}{l}\text { Rajan and Zingales, 2003; Mwangi and Shem, } \\
2012\end{array}$ \\
\hline $\begin{array}{l}\text { Financial } \\
\text { Inclusion }\end{array}$ & $\begin{array}{l}\text { Proxied using both single FI measures } \\
\text { (transactionary, credit, savings and investment, } \\
\text { insurance and pension) and composite FI } \\
\text { indicator (IFI) }\end{array}$ & $+/-$ & $\begin{array}{l}\text { Diagne and Zeller, 2001; Bernerjee et al., } \\
\text { 2009, Honohan and King, 2012; } \\
\text { Demirguc-Kunt et al., 2015; Jovanovic et al., } \\
1990\end{array}$ \\
\hline Own Residence & $\begin{array}{l}\text { Whether the dwelling unit is owned or } \\
\text { otherwise }\end{array}$ & + & $\begin{array}{l}\text { Dercon and Krishnan, 2004; Jalan and } \\
\text { Ravallion, } 1998\end{array}$ \\
\hline Occupation & $\begin{array}{l}\text { Sector where household head works; } \\
\text { employed, agriculture or business }\end{array}$ & $+/-$ & $\begin{array}{l}\text { McCullouch and Calandrino, 2003; Larson and } \\
\text { Plessman, } 2002\end{array}$ \\
\hline
\end{tabular}

Source: Author, 2016.

To control for the unobserved heterogeneity, we included; fc Cohort fixed effect, $\lambda$ the fixed effect for geographical location and $\gamma$ the fixed effect for the survey year shocks such as technological change

\subsection{Estimation Issues}

Use of cohorts in repeated cross sectional data helps creates a pseudo panel which closely approximates a true panel where same households are followed in successive surveys hence facilitating estimation of parameters capturing the dynamic relationship (Deaton, 1986 \& Gurgand et al. 1997). This approach however has potential to diminishe the efficiency of the cross sectional while at the same time introducing heteroscedasticity in the time dimension. It could alsobias expenditure elasticities from errors of specification, measurement or omission of variables (Wooldridge, 2012). These problems were corrected through differencing of the individual panels while heteroscedasticity was corrected through decomposing the data into between and within dimensions and computing the exact heteroscedasticity on both dimensions. Failure to track same individuals over time in repeated cross sectional data may also lead to loss of historical aspects in computing deviations from the means. Despite these shortcomings, seminal work by Deaton (1985) gives assurance that in the absence of a true panel where same individuals are surveyed in each wave, one can exploit repeated cross sectional data to form a pseudo panel which groups individual observations into cohorts comprising households with same observed time invariant characteristics namely; gender, geographical location and year of birth of the household head. The lagged dependent variable (consumption expenditure of the representative household cohort in the preceding survey) is used to estimate the dynamic model. Following Deaton (1986) and Bourguignon, Goh and Kim's (2004), this study uses a cohort mean based approach to track the effect of FI on the household welfare. This method of estimating using subgroups is similar to the method of using instrumental variables to represent certain phenomena where the group indicators serve as instruments. Cull et al. (2013) posits that the channel 
where access to financial services influence income is at least as plausible as the likely mechanism where passing a threshold level of income opens up the opportunity for an individual to access formal banking services.

\subsection{Data}

Suitable data are not available for Kenya as the household surveys do not have a panel dimension for tracking usage of a broad range of financial services and their impacts over time. This study uses repeated $(2009,2013$ and 2016) FinAccess household survey datasets in Kenya to construct a pseudo panel and track household cohorts based on age, gender and location in the three waves. The observed cohort means represent the population mean (Deaton, 1986). A key consideration in cohort analysis is the tradeoff between the number of cohorts and number of observations for each cohort. McKenzie (2004) posits that a large number of cohorts minimize errors associated with small samples.

\section{Estimation Results}

\subsection{Descriptive Statistics}

Table 2 provides a snapshot of the means and standard deviation of variables relevant to the estimation of a welfare function. Consumption per adult equivalent is expressed in Kenya shillings while education is expressed in terms of schooling years by level.

Table 2. Household characteristics

\begin{tabular}{llllll}
\hline Variable & Observations & Mean & Std. Dev. & Min & Max \\
\hline Household size & 378 & 5 & 2.81 & 1 & 20 \\
Age & 378 & 43 & 13.16 & 18 & 68 \\
Education & 378 & 8 & 4.76 & 0 & 14 \\
Female hh head & 378 & 0.26 & 0.44 & 0 & 1 \\
Urban & 378 & 0.40 & 0.49 & 0 & 1 \\
Financial literacy & 378 & 0.78 & 0.41 & 0 & 1 \\
Social capital & 378 & 0.46 & 0.50 & 0 & 1 \\
Consumption expenditure & 378 & 6810 & 19864 & 0 & 263933 \\
Gross income & 378 & 5133 & 13918 & 0 & 166668 \\
Own residence & 378 & 0.65 & 0.48 & 0 & 1 \\
Married & 378 & 0.66 & 0.47 & 0 & 1 \\
Index of Financial Inclusion (IFI) & 378 & 0.12 & 0.12 & 0 & 0.72 \\
Credit & 378 & 0.11 & 0.31 & 0 & 1 \\
Transactionary usage & 378 & 0.63 & 0.48 & 0 & 1 \\
Savings usage & 378 & 0.22 & 0.41 & 0 & 1 \\
Insurance usage & 378 & 0.24 & 0.43 & 0 & 1 \\
Agriculture & 378 & 0.37 & 0.48 & 0 & 1 \\
Employed & 378 & 0.34 & 0.47 & 0 & 1 \\
Business & 378 & 0.11 & 0.32 & 0 & 1 \\
\hline
\end{tabular}

Source: FinAccess survey 2009, 2013 \& 2016.

The descriptive statistics table represents the demographic profile of the 378 observations from the 2009, 2013 and 2016 FinAccess survey cohorts. The number of schooling years averaged 8 an indication that a majority of the sampled population are primary completed. The 0.40 mean in the urban variable signify dominance by rural respondents while the 0.66 mean in the married category imply that a majority are married. The average household size for the tracked cohorts stand at 5 persons. In a bid to understand the profile of sampled households, the study further analyzed the main economic activities on the basis of main income source.

\subsection{Consumption Expenditure across the Country}

Cumulatively, residents of Nairobi region in aggregate terms spent relatively more on consumption (Ksh 50,000 per month) compared to other regions probably due to the high number of well-paying income generating opportunities available plus most of the highest paid employees are situated in Nairobi. This is presented in Figure 1. 


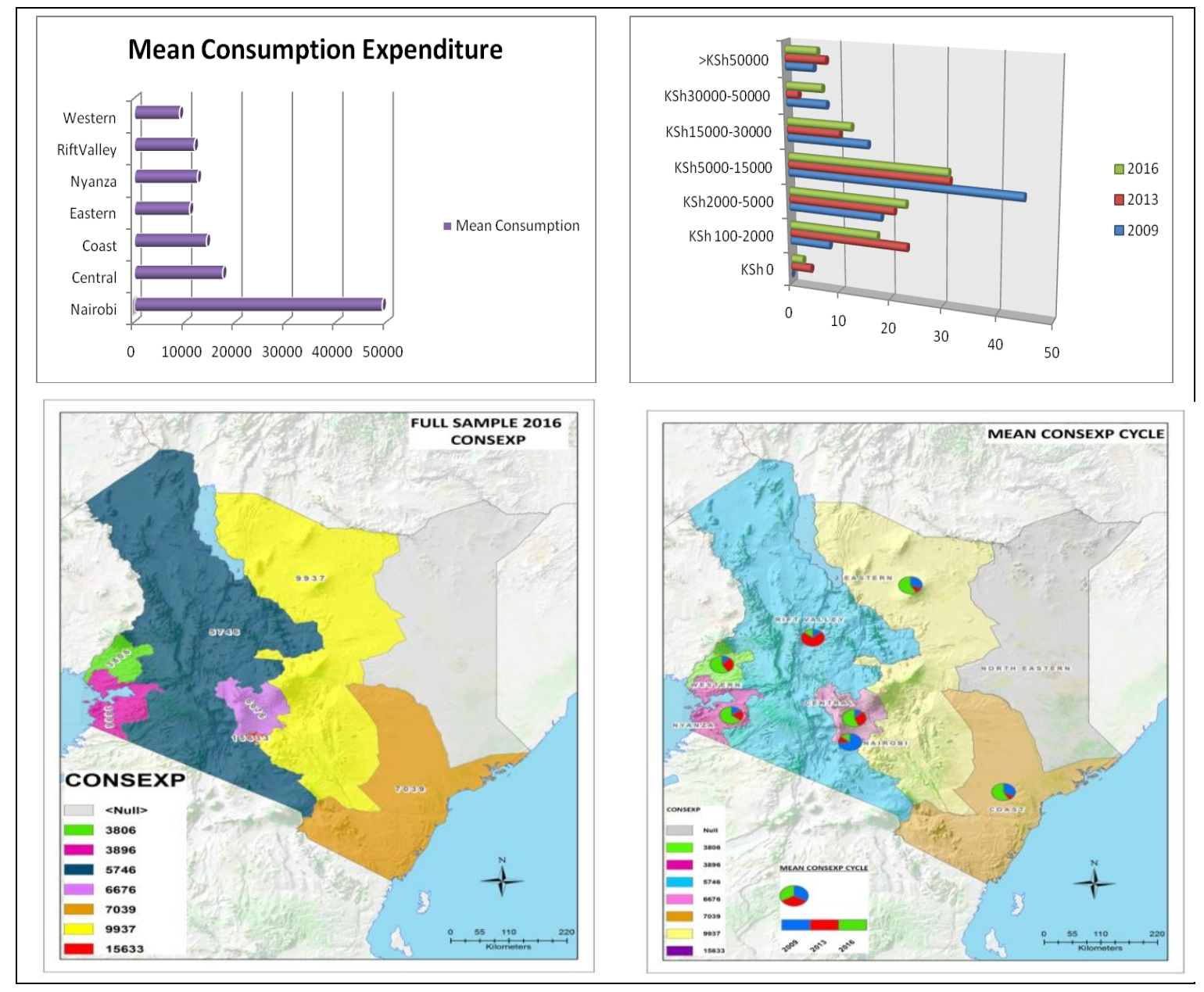

Figure 1. Consumption expenditure across the country

Source: Author, 2016.

Fig 1 excludes data for North Eastern region due to missing 2013 data. Western region trails other regions with less than Ksh 10,000 average consumption expenditure per month. This finding corroborates OPHI (2016) findings based on the KDHS 2013-2014 data which reported high poverty incidence for Western region while Nairobi outshined all other regions. Urban households stand a higher chance of enjoying improved living standards as compared to rural households who face deprivation from many fronts. Expenditure distribution in 2009, was in excess of Ksh 100 for all households. However, as time progressed, the percentage population spending between Ksh 0 - 100 rose sharply in 2013 before stabilizing in 2016. A majority in 2009 spent an average Ksh 30,000 - 50,000 while in both 2013 and 2016 consumption expenditure averaged Ksh 5,000 15,000 . The inscribed pie charts present the progression of per adult equivalent consumption expenditure over the three waves. In aggregate terms, consumption expenditure has improved in 2016 (green shading) in the pie chart.

\subsection{Econometric Results and Discussion}

The dynamic estimation made use of 378 observations (126 cohorts multiplied by 3 survey years) although a lagging of the dependent variable led to a loss of one survey year. Consumption is seen as the main transmission channel for accelerating economic growth (Keynes, 1936). The indirect channel of financial development recognizes the pivotal role played by economic growth in reducing poverty and income inequalities. However, the success in the use of FI as a welfare enhancing tool largely depends on household characteristics and the environment in which they operate. The estimation was carried out both before and after controlling for the unobserved heterogeneity from survey year and region specific effects in the five autoregressive models.

\subsubsection{Testing for Endogeneity}

As mentioned earlier FI and consumption expenditure are potentially endogenous. The Durbin Wu-Haussman test 
was conducted by first running a FI model on the four transmission channels (transactionary, credit, savings, insurance) as well as the aggregated FI channel (IFI) to test for the presence of endogeneity. The residuals for each FI channel were predicted and included in a reduced form equation as regressors. Wooldridge (2012) suggests that failure to reject the null hypothesis (exogeneity assumption) rules out the presence of endogeneity bias. This is represented in Table 3.

Table 3. Durbin-Wu-Haussmann test for Endogeneity

\begin{tabular}{|c|c|c|c|c|c|}
\hline Dependent Variable & (Transactionary) & $(\mathrm{IFI})$ & (Credit) & (Savings) & (Insurance) \\
\hline \multirow[t]{2}{*}{ Log income } & -12.97 & -45.10 & -28.88 & 32.54 & -8.06 \\
\hline & $(31.41)$ & (117.3) & (92.76) & $(222.5)$ & (26.24) \\
\hline \multirow[t]{2}{*}{ Age } & 0.52 & 0.67 & 0.9 & 0.68 & 0.48 \\
\hline & $(0.67)$ & $(0.52)$ & $(1.33)$ & (1.65) & $(0.52)$ \\
\hline \multirow[t]{2}{*}{ Agesqrd } & 0.03 & -0.00 & -0.02 & 0.09 & 0.01 \\
\hline & $(0.27)$ & $(0.19)$ & $(0.40)$ & $(0.71)$ & $(0.14)$ \\
\hline \multirow[t]{2}{*}{ Hhsize } & -0.00 & 0.00 & 0.00 & -0.00 & 0.00 \\
\hline & $(0.00)$ & $(0.00)$ & $(0.00)$ & $(0.01)$ & $(0.00)$ \\
\hline \multirow[t]{2}{*}{ Hhsizesqrd } & -0.14 & -0.07 & 0.33 & -0.00 & -0.15 \\
\hline & $(0.42)$ & $(0.38)$ & $(1.80)$ & (1.29) & $(0.25)$ \\
\hline \multirow[t]{2}{*}{ Femhhhead } & 0.01 & 0.00 & -0.02 & -0.00 & 0.07 \\
\hline & $(0.03)$ & $(0.02)$ & $(0.09)$ & $(0.07)$ & $(0.01)$ \\
\hline \multirow[t]{2}{*}{ Education } & 0.26 & 0.27 & 0.70 & -0.10 & 0.29 \\
\hline & $(1.05)$ & $(0.80)$ & $(2.53)$ & $(2.92)$ & $(0.62)$ \\
\hline \multirow[t]{2}{*}{ Married } & 0.22 & 0.43 & 1.06 & 0.85 & 0.03 \\
\hline & $(1.90)$ & $(1.15)$ & $(2.77)$ & $(4.97)$ & $(1.43)$ \\
\hline \multirow[t]{2}{*}{ Distance } & 0.73 & 0.58 & 0.96 & 0.36 & 0.42 \\
\hline & (1.49) & $(0.98)$ & $(2.51)$ & $(2.15)$ & $(0.59)$ \\
\hline \multirow[t]{2}{*}{ Bank trust } & 0.23 & 0.33 & 0.91 & 0.51 & 0.30 \\
\hline & $(1.19)$ & $(0.75)$ & $(2.85)$ & $(3.24)$ & $(0.53)$ \\
\hline \multirow[t]{2}{*}{ Social capital } & -1.43 & -1.25 & -3.01 & -1.99 & -0.86 \\
\hline & $(2.70)$ & $(2.12)$ & $(8.19)$ & (10.79) & $(1.59)$ \\
\hline \multirow[t]{2}{*}{ Fin literacy } & 13.18 & 43.99 & 21.45 & -34.50 & 9.67 \\
\hline & (32.74) & (116.3) & $(70.22)$ & (236.7) & $(25.57)$ \\
\hline \multirow[t]{2}{*}{ Predicted residuals } & 3.71 & 2.96 & 1.33 & 1.65 & 3.78 \\
\hline & $(6.85)$ & $(5.56)$ & (11.05) & (19.25) & $(4.20)$ \\
\hline Observations & 378 & 378 & 378 & 378 & 378 \\
\hline
\end{tabular}

Robust standard errors in parentheses $* * * \mathrm{p}<0.01, * * \mathrm{p}<0.05, * \mathrm{p}<0.1$.

Since the predicted residuals in the structural equation were not statistically significant, we failed to reject the null hypothesis. This ruled out the need to instrument the various FI channels since FI was found to be exogenous. A panel estimation of the impact of FI on household welfare using Arrelano and Bover (1995) system GMM ensues to counter the Hurwicz/Nickel bias associated with FE/RE models which ends up underestimating the autoregressive coefficient leading to a bias of order 1/T (Wooldridge, 2012).

\subsubsection{Linear Dynamic Estimation}

Deaton (1992) introduced time non separable preferences to inform on habit formation among households where utility derived from present consumption was expressed as a function of both present and past consumption behaviour. A two-step GMM estimation established varying welfare effects of FI for the five autoregressive models. The essence of panel estimation is to eliminate fixed effects through differencing.

\subsubsection{Dynamic Welfare Estimation (Durbin-Wu-Haussmann Approach)}

Control functions are applied when panel data models contain unobserved heterogeneity and omitted time varying variables hence best suited for correcting both endogeneity and heterogeneity problems in nonlinear models. (Wooldridge, 2012). It's based on an estimation of the structural form equation including the predicted residuals and the observed endogenous variable. Five autoregressive dynamic control functions were estimated to establish the true effect of FI on household consumption per adult equivalent with each model representing a particular FI product in Table 4. 
Table 4. Dynamic control function of consumption expenditure

\begin{tabular}{|c|c|c|c|c|c|}
\hline \multirow[t]{2}{*}{ Dependent } & (Welfare) & (Welfare) & (Welfare) & (Welfare) & (Welfare) \\
\hline & IFI & Transactionary & Credit & Savings & Insurance \\
\hline \multirow[t]{2}{*}{ Lag welfare } & 0.036 & 0.045 & 0.048 & 0.046 & 0.019 \\
\hline & $(0.061)$ & $(0.062)$ & $(0.062)$ & $(0.064)$ & $(0.060)$ \\
\hline \multirow[t]{2}{*}{ log Income } & 0.114 & $0.729 * * *$ & $0.687 * * *$ & $0.508 * * *$ & $0.532 * * *$ \\
\hline & $(0.330)$ & $(0.068)$ & $(0.074)$ & $(0.105)$ & $(0.135)$ \\
\hline \multirow[t]{2}{*}{ Age } & $0.185^{*}$ & 0.046 & 0.018 & 0.093 & 0.076 \\
\hline & $(0.105)$ & $(0.072)$ & $(0.081)$ & $(0.085)$ & $(0.084)$ \\
\hline \multirow[t]{2}{*}{ Agesqrd } & $-0.002 *$ & -0.001 & -0.000 & -0.001 & -0.001 \\
\hline & $(0.001)$ & $(0.001)$ & $(0.001)$ & $(0.001)$ & $(0.001)$ \\
\hline \multirow[t]{2}{*}{ Hhsize } & $-0.393^{* * *}$ & $-0.131^{*}$ & $-0.153^{* *}$ & $-0.212 * *$ & $-0.164 * *$ \\
\hline & $(0.152)$ & $(0.071)$ & $(0.073)$ & $(0.088)$ & $(0.079)$ \\
\hline \multirow[t]{2}{*}{ Hhsizesqrd } & $0.018 * * *$ & 0.006 & $0.008^{*}$ & $0.010^{* *}$ & $0.008^{*}$ \\
\hline & $(0.007)$ & $(0.004)$ & $(0.004)$ & $(0.005)$ & $(0.004)$ \\
\hline \multirow[t]{2}{*}{ Femhhhead } & 0.148 & 0.097 & 0.284 & 0.083 & 0.028 \\
\hline & (0.194) & $(0.225)$ & $(0.331)$ & $(0.211)$ & $(0.237)$ \\
\hline \multirow[t]{2}{*}{ Education } & 0.0759 & $0.842 * * *$ & $0.795^{* * *}$ & 0.356 & $0.509 *$ \\
\hline & $(0.441)$ & $(0.225)$ & $(0.215)$ & $(0.267)$ & $(0.264)$ \\
\hline \multirow[t]{2}{*}{ Married } & 0.143 & -0.139 & 0.0489 & -0.0284 & -0.122 \\
\hline & $(0.219)$ & $(0.222)$ & $(0.278)$ & $(0.192)$ & $(0.202)$ \\
\hline \multirow[t]{2}{*}{ Social capital } & -0.177 & -0.056 & -0.057 & -0.049 & -0.055 \\
\hline & $(0.185)$ & $(0.189)$ & $(0.274)$ & $(0.201)$ & $(0.213)$ \\
\hline \multirow[t]{2}{*}{ Own residence } & -0.0595 & -0.158 & -0.0280 & -0.139 & -0.0561 \\
\hline & $(0.174)$ & $(0.189)$ & $(0.196)$ & (0.199) & $(0.203)$ \\
\hline \multirow[t]{2}{*}{ FI Measure } & $3.473 * * *$ & $0.743 * * *$ & $0.816^{* * *}$ & 0.0873 & $0.398 *$ \\
\hline & $(1.125)$ & $(0.284)$ & $(0.243)$ & (0.194) & $(0.210)$ \\
\hline \multirow[t]{2}{*}{ Ehat } & 13.81 & $-1.777^{*}$ & -1.382 & $1.867 *$ & 0.695 \\
\hline & (10.95) & $(0.974)$ & (1.188) & (1.113) & (1.019) \\
\hline \multirow[t]{2}{*}{ Central } & -0.232 & -0.453 & $-0.590 * *$ & $-0.893 * * *$ & $-1.022 * *$ \\
\hline & $(0.406)$ & $(0.307)$ & $(0.301)$ & $(0.328)$ & $(0.436)$ \\
\hline \multirow[t]{2}{*}{ Coast } & 1.366 & -0.0336 & 0.0274 & 0.592 & 0.0197 \\
\hline & $(0.920)$ & $(0.404)$ & $(0.388)$ & $(0.476)$ & $(0.367)$ \\
\hline \multirow[t]{2}{*}{ Eastern } & 0.351 & -0.259 & -0.389 & -0.321 & -0.539 \\
\hline & $(0.644)$ & $(0.380)$ & $(0.397)$ & $(0.408)$ & $(0.421)$ \\
\hline \multirow[t]{2}{*}{ Nyanza } & 0.152 & 0.161 & -0.0739 & 0.0410 & -0.520 \\
\hline & $(0.394)$ & $(0.373)$ & $(0.365)$ & $(0.347)$ & $(0.491)$ \\
\hline \multirow[t]{2}{*}{ R.Valley } & -0.229 & $-1.291 * *$ & $-1.106 * *$ & -0.695 & $-1.518 * *$ \\
\hline & $(0.768)$ & $(0.525)$ & $(0.482)$ & $(0.568)$ & $(0.647)$ \\
\hline \multirow[t]{2}{*}{ Western } & -0.156 & 0.0158 & -0.210 & -0.328 & -0.644 \\
\hline & $(0.409)$ & $(0.412)$ & $(0.408)$ & $(0.431)$ & $(0.515)$ \\
\hline \multirow[t]{2}{*}{ Agriculture } & 0.329 & $0.992 * * *$ & $0.695^{* *}$ & $0.828 * * *$ & $0.813 * * *$ \\
\hline & $(0.376)$ & $(0.355)$ & $(0.319)$ & $(0.265)$ & $(0.268)$ \\
\hline Employed & 0.092 & $0.891 * *$ & $0.675^{* *}$ & $0.617^{* *}$ & $0.558^{*}$ \\
\hline & $(0.463)$ & $(0.371)$ & $(0.273)$ & $(0.260)$ & $(0.291)$ \\
\hline Business & -1.188 & $1.361 * *$ & $0.898 * * *$ & 0.305 & $0.736^{*}$ \\
\hline & (1.457) & $(0.530)$ & $(0.333)$ & $(0.535)$ & $(0.416)$ \\
\hline 2013 & 2.611 & -0.175 & -0.060 & 0.502 & 0.191 \\
\hline & (1.671) & $(0.240)$ & $(0.204)$ & $(0.350)$ & $(0.225)$ \\
\hline Observations & 252 & 252 & 252 & 252 & 252 \\
\hline R-squared & 0.840 & 0.838 & 0.837 & 0.823 & 0.825 \\
\hline
\end{tabular}

Robust standard errors in parentheses *** $\mathrm{p}<0.01, * * \mathrm{p}<0.05, * \mathrm{p}<0.1$.

This model is considered to be more robust due to its ability to control for unobserved heterogeneity in the error term as FI changes. The estimated FI parameter therefore represents the true effect holding all other factors constant. Differences observed in the welfare are therefore solely attributed to changes in FI. To the extent that the coefficient of the predicted residuals fails the significance test, then OLS estimates are consistent. Consistent with theory, findings from the econometric estimation of consumption per adult equivalent revealed a strong positive relationship between FI and per adult equivalent consumption expenditure at 1 percent under the IFI (3.473), credit (0.816) and transactionary (0.743) channels. This result conforms to findings by Sarma (2008); Honohan and King 
(2012). The household head consumption per adult equivalent also improved by 0.398 at 10 percent significance level for the insurance autoregressive dynamic panel.

The interpretation of a zero-one dummy is however not so direct since it's based on the shift from non-usage to usage. A shift from non-usage to usage of financial services among households raises household welfare by 126 , 110 and 49 percent with respect to credit, transactionary and insurance products respectively. Conversely, a counterfactual assessment where movement is from usage to non-usage of financial services revealed a 56, 52 and 33 percent drop in welfare for credit, transactionary and insurance products respectively. Portfolio usage of financial services as captured by the index of financial inclusion raised household welfare by 347 percent other factors held constant.

As expected, per capita income was significant at 1 percent in explaining a household welfare function along the four transmission channels in line with Keynes (1936); Friedman (1957), Modigliani (1963), and Duesenberry (1949) prediction. Household size exhibited an inverse quadratic relationship on welfare along the five autoregressive dynamic channels (IFI, transactionary, credit, savings and insurance). This inverse relationship implies that having a household with few members may not automatically translate to improved welfare. There is need however to determine the optimal household size. The coefficient of education variable which simply measures schooling years reinforces the critical role played by the human capital theory in linking education to improved welfare. Skilled people are well able to manage their financial products more efficiently by holding fewer but quality products.

The regression model was based on 97 cohorts from each repeated FinAccess survey (2009, 2013 and 2016). To control for unobserved heterogeneity which could be inherent in the data, we re-estimated the dynamic control function including an interaction term between the predicted residuals and the FI measure. Unobserved heterogeneity occurs when the unobserved household effects are combined with the policy variable to vary the effects in each model. The coefficient of the predicted residual represents the exaggeration effect of the policy variable. This is illustrated in Table 5.

Table 5. Dynamic control function corrected for heterogeneity

\begin{tabular}{|c|c|c|c|c|c|}
\hline Dependent & $\begin{array}{l}\text { (Welfare) } \\
\text { IFI }\end{array}$ & $\begin{array}{l}\text { (Welfare) } \\
\text { Transactionary }\end{array}$ & $\begin{array}{l}\text { (Welfare) } \\
\text { Credit }\end{array}$ & $\begin{array}{l}\text { (Welfare) } \\
\text { Savings }\end{array}$ & $\begin{array}{l}\text { (Welfare) } \\
\text { Insurance }\end{array}$ \\
\hline Lag consumption & $\begin{array}{l}0.030 \\
(0.061)\end{array}$ & $\begin{array}{l}0.045 \\
(0.062)\end{array}$ & $\begin{array}{l}0.049 \\
(0.062)\end{array}$ & $\begin{array}{l}0.046 \\
(0.064)\end{array}$ & $\begin{array}{l}0.038 \\
(0.059)\end{array}$ \\
\hline log income & $\begin{array}{l}0.192 \\
(0.337)\end{array}$ & $\begin{array}{l}0.729 * * * \\
(0.068)\end{array}$ & $\begin{array}{l}0.681 * * * \\
(0.079)\end{array}$ & $\begin{array}{l}0.508 * * * \\
(0.105)\end{array}$ & $\begin{array}{l}0.494 * * * \\
(0.134)\end{array}$ \\
\hline age & $\begin{array}{l}0.161 \\
(0.107)\end{array}$ & $\begin{array}{l}0.045 \\
(0.073)\end{array}$ & $\begin{array}{l}0.021 \\
(0.081)\end{array}$ & $\begin{array}{l}0.092 \\
(0.085)\end{array}$ & $\begin{array}{l}0.112 \\
(0.089)\end{array}$ \\
\hline agesqrd & $\begin{array}{l}-0.001 \\
(0.001)\end{array}$ & $\begin{array}{l}-0.001 \\
(0.001)\end{array}$ & $\begin{array}{l}-0.000 \\
(0.001)\end{array}$ & $\begin{array}{l}-0.001 \\
(0.001)\end{array}$ & $\begin{array}{l}-0.001 \\
(0.001)\end{array}$ \\
\hline hhsize & $\begin{array}{l}-0.363 * * \\
(0.152)\end{array}$ & $\begin{array}{l}-0.131 * \\
(0.071)\end{array}$ & $\begin{array}{l}-0.154 * * \\
(0.073)\end{array}$ & $\begin{array}{l}-0.212 * * \\
(0.089)\end{array}$ & $\begin{array}{l}-0.168 * * \\
(0.080)\end{array}$ \\
\hline hhsizesqrd & $\begin{array}{l}0.017 * * \\
(0.007)\end{array}$ & $\begin{array}{l}0.006 \\
(0.004)\end{array}$ & $\begin{array}{l}0.008^{*} \\
(0.004)\end{array}$ & $\begin{array}{l}0.010^{* *} \\
(0.005)\end{array}$ & $\begin{array}{l}0.008^{*} \\
(0.004)\end{array}$ \\
\hline femhhhead & $\begin{array}{l}0.138 \\
(0.192)\end{array}$ & $\begin{array}{l}0.098 \\
(0.227)\end{array}$ & $\begin{array}{l}0.268 \\
(0.345)\end{array}$ & $\begin{array}{l}0.089 \\
(0.214)\end{array}$ & $\begin{array}{l}-0.013 \\
(0.234)\end{array}$ \\
\hline education & $\begin{array}{l}0.172 \\
(0.460)\end{array}$ & $\begin{array}{l}0.846 * * * \\
(0.231)\end{array}$ & $\begin{array}{l}0.787 * * * \\
(0.219)\end{array}$ & $\begin{array}{l}0.359 \\
(0.268)\end{array}$ & $\begin{array}{l}0.447 * \\
(0.263)\end{array}$ \\
\hline married & $\begin{array}{l}0.108 \\
(0.227)\end{array}$ & $\begin{array}{l}-0.139 \\
(0.222)\end{array}$ & $\begin{array}{l}0.046 \\
(0.279)\end{array}$ & $\begin{array}{l}-0.021 \\
(0.195)\end{array}$ & $\begin{array}{l}-0.178 \\
(0.193)\end{array}$ \\
\hline social capital & $\begin{array}{l}-0.160 \\
(0.186)\end{array}$ & $\begin{array}{l}-0.054 \\
(0.192)\end{array}$ & $\begin{array}{l}-0.085 \\
(0.292)\end{array}$ & $\begin{array}{l}-0.048 \\
(0.202)\end{array}$ & $\begin{array}{l}-0.044 \\
(0.210)\end{array}$ \\
\hline residence_own & $\begin{array}{l}-0.056 \\
(0.169)\end{array}$ & $\begin{array}{l}-0.157 \\
(0.186)\end{array}$ & $\begin{array}{l}-0.030 \\
(0.195)\end{array}$ & $\begin{array}{l}-0.142 \\
(0.200)\end{array}$ & $\begin{array}{l}0.050 \\
(0.230)\end{array}$ \\
\hline FI Measure & $\begin{array}{l}4.772^{*} \\
(2.447)\end{array}$ & $\begin{array}{l}0.796 \\
(0.626)\end{array}$ & $\begin{array}{l}1.002^{*} \\
(0.581)\end{array}$ & $\begin{array}{l}0.165 \\
(0.400)\end{array}$ & $\begin{array}{l}-0.236 \\
(0.405)\end{array}$ \\
\hline ehat & $\begin{array}{l}11.72 \\
(11.26)\end{array}$ & $\begin{array}{l}-1.679 \\
(1.600)\end{array}$ & $\begin{array}{l}-1.176 \\
(1.407)\end{array}$ & $\begin{array}{l}1.895^{*} \\
(1.146)\end{array}$ & $\begin{array}{l}0.691 \\
(0.999)\end{array}$ \\
\hline ehat_FI & $\begin{array}{l}-4.015 \\
(5.139)\end{array}$ & $\begin{array}{l}-0.108 \\
(1.122)\end{array}$ & $\begin{array}{l}-0.488 \\
(1.207)\end{array}$ & $\begin{array}{l}-0.145 \\
(0.712)\end{array}$ & $\begin{array}{l}1.203^{*} \\
(0.634)\end{array}$ \\
\hline Central & $\begin{array}{l}-0.346 \\
(0.424) \\
\end{array}$ & $\begin{array}{l}-0.456 \\
(0.307)\end{array}$ & $\begin{array}{l}-0.598 * * \\
(0.300) \\
\end{array}$ & $\begin{array}{l}-0.891 * * * \\
(0.329)\end{array}$ & $\begin{array}{l}-1.160 * * \\
(0.457) \\
\end{array}$ \\
\hline
\end{tabular}




\begin{tabular}{llllll}
\hline Coast & 1.147 & -0.028 & 0.053 & 0.595 & -0.049 \\
Eastern & $(0.943)$ & $(0.422)$ & $(0.407)$ & $(0.479)$ & $(0.378)$ \\
& 0.205 & -0.261 & -0.384 & -0.315 & -0.698 \\
Nyanza & $(0.656)$ & $(0.377)$ & $(0.398)$ & $(0.414)$ & $(0.445)$ \\
& 0.094 & 0.158 & -0.0842 & 0.0443 & -0.771 \\
R.Valley & $(0.395)$ & $(0.373)$ & $(0.367)$ & $(0.348)$ & $(0.519)$ \\
& -0.405 & $-1.291^{* *}$ & $-1.125^{* *}$ & -0.690 & $-1.675^{* *}$ \\
Western & $(0.801)$ & $(0.525)$ & $(0.481)$ & $(0.569)$ & $(0.678)$ \\
& -0.213 & 0.013 & -0.223 & -0.332 & -0.838 \\
Agriculture & $(0.407)$ & $(0.410)$ & $(0.406)$ & $(0.429)$ & $(0.541)$ \\
& 0.418 & $0.988^{* * *}$ & $0.695^{* *}$ & $0.828^{* * *}$ & $0.905^{* * *}$ \\
Employed & $(0.391)$ & $(0.365)$ & $(0.319)$ & $(0.266)$ & $(0.265)$ \\
& 0.214 & $0.885^{* *}$ & $0.660^{* *}$ & $0.620^{* *}$ & $0.548^{*}$ \\
Business & $(0.473)$ & $(0.387)$ & $(0.277)$ & $(0.261)$ & $(0.282)$ \\
& -0.757 & $1.355^{* *}$ & $0.884 * * *$ & 0.336 & 0.606 \\
2013 & $(1.552)$ & $(0.553)$ & $(0.332)$ & $(0.530)$ & $(0.407)$ \\
& 2.290 & -0.176 & -0.049 & 0.502 & 0.225 \\
Observations & $(1.703)$ & $(0.237)$ & $(0.210)$ & $(0.350)$ & $(0.212)$ \\
R-squared & 252 & 252 & 252 & 252 & 252 \\
\hline
\end{tabular}

Robust standard errors in parentheses *** $\mathrm{p}<0.01, * * \mathrm{p}<0.05, * \mathrm{p}<0.1$.

\section{Conclusions and Policy Implications}

This paper aimed at investigating the impact of financial inclusion (FI) on consumption per adult equivalent. Five autoregressive dynamic models were estimated to measure the impact of FI (transactionary, credit, savings, insurance, IFI) since each channel is believed to contribute differently to the observed differences in consumption per adult equivalent among households. The dynamic welfare estimates revealed that unobserved region and sector specific effects were significant in explaining variation in individual consumption expenditure.

Consistent with economic theory, transactionary, credit, insurance and index of FI (IFI) exhibited a strong positive impact on household welfare vindicating the ongoing reforms in the financial sector as a necessary tool for enhancing household welfare. Even though use of the lagged dependent variable in a pseudo panel estimation may not yield robust estimates due to the use of aggregated data organized in cohorts, the technique is often considered to be superior in the absence of longitudinal data for tracking households over time.

Increasing the range of formal financial products as well as improving measures of FI to focus more on the quality could go a long way in enhancing a more competitive financial market leading to a reduction in transactionary costs. Transferring the gains from the reduction in product costs to the households can have immense welfare benefits. An inclusive financial system should also target other dimensions of financial inclusion such as impact and policy centred on performance at both the national and county levels. In addition, policies targeting welfare improvement through finance should be aligned to specific financial inclusion transmission channels to be more effective as opposed to blanket recommendations.

\section{References}

Aghion, P., \& Bolton, P. (1997). A Theory of Trickle-Down Growth and Development. The Review of Economic Studies, 64(2), 151-172. https://doi.org/10.2307/2971707

Amidzic, G., Massara, A., \& Mialou, A. (2014). Assessing Countries Financial Inclusion Standing: A New Composite Index. IMF Working Papers, 14(36), 1. https://doi.org/10.5089/9781475569681.001

Ando, A., \& Modigliani, F. (1963). The Life Cycle Hypothesis of Saving: Aggregate Implications and Tests. American Economic Review, 53(1), 55-84.

Angelucci, M., Karlan, D., \& Zinman. J. (2015). Microcredit Impacts: Evidence from a Randomized Microcredit Program Placement Experiment by Compartamos Banco: Dataset. American Economic Journal, 7(1), 151-182. https://doi.org/10.1257/app.20130537

Arellano, M., \& Bover, O. (1995). Another look at the instrumental variable estimation of error-components models. Journal of Econometrics, 68(1), 29-51. https://doi.org/10.1016/0304-4076(94)01642-D

Attanasio, O., Augsburg, B., Haas, R. D., Fitzsimons, E., \& Harmgart, H. (2011). Group Lending or Individual Lending? Evidence from a Randomized Field Experiment in Rural Mongolia. Working Paper, 11(20). London: Institute of Fiscal Studies. 
Banerjee, A., Karlan, D., \& Zinman, J. (2015). Six Randomized Evaluations of Microcredit: Introduction and Further Steps. American Economic Journal: Applied Economics, 7(1), 1-21. https://doi.org/10.1257/app.20140287

Bauchet, J., Cristobal M., Laura S., Jeanette T., \& Anna Y. (2011). Latest Findings from Randomized Evaluations of Microfinance. Access to Finance Forum, 2. Consultative Group to Assist the Poor (CGAP), Washington, DC. https://doi.org/10.1596/26892

Beck, T., Demirgüç-Kunt, A., \& Levine, R. (2004). Finance, Inequality, and Poverty: Cross-Country Evidence. Policy Research Working Papers. https://doi.org/10.3386/w10979

Beck. (2016). Financial Inclusion in Africa. Cass Business School, London.

Bourguignon, F., Goh, C., \& Kim, D. I. (2004). Estimating Individual Vulnerability to Poverty with Pseudo-Panel Data. Policy Research Working Papers, 3375. https://doi.org/10.1596/1813-9450-3375

Buera, F., Kaboski, J., \& Shin, Y. (2012). The Macroeconomics of Microfinance. NBER Working Papers, 17905, National Bureau of Economic Research, Inc. https://doi.org/10.3386/w17905

Burney, N. A., \& Akmal, M. (1991). Food Demand in Pakistan: An Application of the Extended Linear Expenditure System. Journal of Agricultural Economics, 42(2), 185-195. https://doi.org/10.1111/j.1477-9552.1991.tb00347.x

Central Bank of Kenya, Kenya National Bureau of Statistics \& Financial Sector Deepening Kenya (2016). FinAccess Household Survey. Nairobi, Kenya.

Central Bank of Kenya, Kenya National Bureau of Statistics \& Financial Sector Deepening Kenya (2013). FinAccess Household Survey. Nairobi, Kenya.

Central Bank of Kenya, Kenya National Bureau of Statistics \& Financial Sector Deepening Kenya (2009). The 2016 FinAccess Household Survey on financial inclusion. Nairobi, Kenya.

Central Bank of Kenya, Kenya National Bureau of Statistics \& Financial Sector Deepening Kenya (2006). The 2016 FinAccess Household Survey on financial inclusion. Nairobi, Kenya.

Chuah, H. L., \& Thai, V. (2004). Financial Development and Economic Growth: Evidence from Causality Tests for the GCC Countries. IMF Working Paper, No. 04.

Copestake, J. (2007). Mainstreaming Microfinance: Social Performance Management or Mission Drift? World Development, 35(10), 1721-1738. https://doi.org/10.1016/j.worlddev.2007.06.004

Crépon, B., Devoto, F., Duflo, E., \& Pariente, W. (2014). Estimating the Impact of Microcredit on Those Who Take It Up: Evidence from a Randomized Experiment in Morocco.

Cull, R., Demirgüç-Kunt, A., \& Morduch, J. (2013). Banks and Microbanks. Journal of Financial Services Research, 46(1), 1-53. https://doi.org/10.1007/s10693-013-0177-z

Deaton. (2001). Understanding Consumption (pp. 40-45). London: Clarendo Press.

Demetriades, P. O., \& Hussein, K. A. (1996). Does financial development cause economic growth? Time-series evidence from 16 countries. Journal of Development Economics, 51(2), 387-411. https://doi.org/10.1016/S0304-3878(96)00421-X

Demirguc-Kunt, A., \& Klapper, L. (2012). Measuring Financial Inclusion: The Global Findex Database. Policy Research Working Paper, No, 6025. Washington, D.C.: World Bank.

Dhrifi, A. (2013). A Revisit of the Growth Inequality Poverty Relationship: The Role of Institutional Quality. International Journal of Advances in Management and Economics, 2(1), 94-102.

Duesenberry, J. (1948). Income-Consumption Relations and their Implications. In L. Metzler (Ed.), Income, Employment and Public Policy.

Dupas, P., \& Robinson, J. (2013). Savings Constraints and Microenterprise Development: Evidence from a Field Experiment in Kenya. American Economic Journal: Applied Economics, 5(1), 163-192. https://doi.org/10.1257/app.5.1.163

Eswaran, \& Kotwal. (1990). Implications of Credit Constraints for Risk Behaviour in Less Developed Economies. Oxford Economic Papers, 42, 473-482. https://doi.org/10.1093/oxfordjournals.oep.a041958

Fama, E. F. (1970). Efficient Capital Markets: A Review of Theory and Empirical Work. The Journal of Finance, 25(2), 383-417. https://doi.org/10.2307/2325486 
Friedman, M. (1957). A Theory of the Consumption Function. Princeton, NJ: Princeton Univerity Press.

Giné, X., \& Townsend, R. M. (2004). Evaluation of financial liberalization: A general equilibrium model with constrained occupation choice. Journal of Development Economics, 74(2), 269-307. https://doi.org/10.1016/j.jdeveco.2003.03.005

Government of Kenya, National Development Plan. (2002-2008). Effective Management for Sustainable Economic Growth and Poverty Reduction. Government Printer.

Government of Kenya. (1994). Welfare Monitoring Survey. Government Printers, Nairobi.

Government of Kenya. (2004). The Economic Recovery Strategy for Wealth and Employment Creation, 2003-2004. Government Printer, Nairobi.

Government of Kenya. (2007). Kenya Vision 2030, Nairobi: Ministry of Planning and National Development. Retrieved from http://www.vision2030.go.ke/

Greenwood, J., \& Jovanovic, B. (1990). Financial Development, Growth, and the Distribution of Income. Journal of Political Economy, 98(51), 1076-1107. https://doi.org/10.1086/261720

Honohan, P. (2008). Cross-country variation in household access to financial services. Journal of Banking \& Finance, 32(11), 2493-2500. https://doi.org/10.1016/j.jbankfin.2008.05.004

International Monetary Fund. (2012). Financial Access Survey, Statistics Department.

Jain, L. R., \& Tendulkar, S. D. (1973). Analysis of Occupational Differences in Consumer Expenditure Patterns in India. Sankhyd, 35(2), 239-267.

Jeong, H., \& Townsend, R. M. (2007). Sources of TFP growth: Occupational choice and financial deepening. Economic Theory, 32(1), 179-221. https://doi.org/10.1007/s00199-006-0201-8

Kaboski, J. P., \& Townsend, R. M. (2012). The Impact of Credit on Village Economies. American Economic Journal: Applied Economics, 4(2), 98-133. https://doi.org/10.1257/app.4.2.98

Karlan, D., \& Zinman, J. (2009). Expanding Credit Access: Using Randomized Supply Decisions to Estimate the Impacts. Review of Financial Studies, 23(1), 433-464. https://doi.org/10.1093/rfs/hhp092

Kenya National Bureau of Statistics (KNBS). (2006). Kenya Integrated Household Budget Survey 2005-2006. Nairobi, Kenya.

Kenya National Bureau of Statistics (KNBS). (2008). Demographic and Health Survey, 2008-2009. Nairobi, Kenya.

Kenya National Bureau of Statistics (KNBS). (2008). Well-Being in Kenya, a socio-economic profile. Nairobi, Kenya.

Kenya National Bureau of Statistics (KNBS). (2014). Demographic and Health Survey, 2013-2014. Nairobi, Kenya.

Keynes, J. M. (1936). The General Theory of Employment Interest and Money. Macmillan: London Press.

Keynes, J. M. (1937). Alternative Theories of the Rate of Interest. The Economic Journal, 47(186), 241-252. https://doi.org/10.2307/2225525

King, R. G., \& Levine, R. (1993). Finance and Growth: Schumpeter Might Be Right. The Quarterly Journal of Economics, 108(3), 717-737. https://doi.org/10.2307/2118406

Knight, J., Shi, L., \& Quheng, D. (2010). Education and the Poverty Trap in Rural China: Closing the Trap. Oxford Development Studies, 38(1), 1-24. https://doi.org/10.1080/13600810903551595

Lanjouw, P., \& Ravallion, M. (1995). Poverty and Household Size. The Economic Journal, 105(433), 1415-1434. https://doi.org/10.2307/2235108

Levine, R. (2008). Finance and The Poor. Manchester School, 76, 1-13. https://doi.org/10.1111/j.1467-9957.2008.01078.x

Lucas, R. E. (1988). On the mechanics of economic development. Journal of Monetary Economics,22(1), 3-42. https://doi.org/10.1016/0304-3932(88)90168-7

McFadden, D. (1978). Modeling the choice of residential location. In A. Kar-lquist et al. (Eds.), Spatial interaction theory and residential location (pp. 75-96). North-Holland, Amsterdam.

Mckenzie, D. J. (2004). Asymptotic theory for heterogeneous dynamic pseudo-panels. Journal of Econometrics, 
120(2), 235-262. https://doi.org/10.1016/S0304-4076(03)00213-6

Mckinnon, R. I. (1974). Money and Capital in Economic Development. International Journal, 29(4), 649. https://doi.org/10.2307/40201473

Merton, R. C. (1992). Financial Innovation and Economic Performance. Journal of Applied Corporate Finance, 4(4), 12-22. https://doi.org/10.1111/j.1745-6622.1992.tb00214.x

Mukherjee, S., \& Benson, T. (2003). The Determinants of Poverty in Malawi, 1998. World Development, 31(2), 339-358. https://doi.org/10.1016/S0305-750X(02)00191-2

Oxford Poverty and Human Development Initiative (OPHI). (2013). Kenya country briefing. Multidimensional Poverty Index Data Bank, OPHI, University of Oxford.

Oxford Poverty and Human Development Initiative (OPHI). (2016). Kenya country briefing. Multidimensional Poverty Index Data Bank, OPHI, University of Oxford.

Pitt, M., \& Khandker, S. (1998). The impact of Group - Based Credit Programs on Poor Households in Bangladesh: Does the Gender of Participants Matter? Journal of Political Economy, 106(5), 958-996. https://doi.org/10.1086/250037

Rajan, R., \& Zingales, L. (1998). Financial Dependence and Growth. American Economic Review, 88(3), 559-586.

Ravallion, M. (1992). Poverty comparisons: A guide to concepts and methods (Washington DC, World Bank).

Robinson, J. (1952). The Generalization of the General Theory. In The Rate of Interest and Other Essays (pp. 67-142). London: MacMillan Publishing Company.

Romer, P. M. (1986). Increasing Returns and Long-Run Growth. Journal of Political Economy, 94(5), 1002-1037. https://doi.org/10.1086/261420

Sarma, M. (2008). Index of Financial Inclusion. A Concept Note. ICRIER Working paper No. 215. Indian Council for Research in International Economic Relations, New Delhi.

Schumpeter, J. A. (1911). Theory of Economic Development. Havard University Press.

Schumpeter, J. A. (1934). Theory of Economic Development: An Inquiry Profits, Capital, Credit, Interest, and the Business Cycle. Cambridge, Mass: Havard University Press.

Stern, N. (1989). The Economics of Development: A Survey. The Economic Journal, 99(397), 597. https://doi.org/10.2307/2233764

Stiglitz, \& Weiss. (1981). Credit rationing in credit markets with imperfect information. American Economic Review, 71.

UN General Assembly. (2000). United Nations Millennium Declaration, Resolution Adopted by the General Assembly, 18 September 2000.

Verbeek, M., \& Vella, F. (2005). Estimating dynamic models from repeated cross-sections. Journal of Econometrics, 127(1), 83-102. https://doi.org/10.1016/j.jeconom.2004.06.004

Wooldridge, J. M. (2010). Econometric Analysis of Cross Section and Panel Data (2nd ed.). Cambridge, MA: MIT Press.

Zeldes. (2005). Consumption and Liquidity Constraints: An empirical investigation. Journal of Political Economy, 2(3), 15-20.

\section{Note}

Note 1. Chapter One: Access to Finance and Development, Theory and Measurement.

\section{Copyrights}

Copyright for this article is retained by the author(s), with first publication rights granted to the journal.

This is an open-access article distributed under the terms and conditions of the Creative Commons Attribution license (http://creativecommons.org/licenses/by/4.0/). 